\title{
Comparison of the Isolation Methods of Viral Nucleic Acids
}

\author{
Nagehan Şakrucu ${ }^{1}$, Uğur Sıdal ${ }^{1 *}$, Tamer Şanlıdağ ${ }^{2}$ \\ 1. Manisa Celal Bayar University, Faculty of Science and Arts, Department of Biology, Manisa, Turkey \\ 2. Manisa Celal Bayar University, Faculty of Medicine, Department of Microbiology, Manisa, Turkey \\ *ugur.sidal@cbu.edu.tr
}

Received: 8 November 2017

Accepted: 25 September 2018

DOI: $10.18466 /$ cbayarfbe. 350005

\begin{abstract}
In vitro amplification of the nucleic acids (DNA or RNA) is used in the detection of microbial agents and thus in the diagnosis of infectious diseases, as well as in the diagnoses of oncological and genetic disorders and forensic medicine. The aim of the present study was to compare the isolation methods of the nucleic acids of hepatitis $\mathrm{B}$ and $\mathrm{C}$ viruses, causative agents of the two significant infections worldwide. Conventional isolation methods were compared with the commercial kits that have been used commonly in recent years, in terms of reliability, cost-effectiveness, contamination risk and duration of the testing time. Five standards for the isolation of the viral nucleic acids of both HBV DNA (Fluorion HBV QNP 2.0) and HCV RNA (Fluorion HCV QNP 2.1) were used. The isolations of the viral nucleic acids of HBV and HCV were done with the conventional methods, phenol-chloroform and guanidine thiocyanate, and the commercial kits Roboscreen and NucleoSpin. The resultant viral nucleic acid load was determined with a spectrophotometer (WPA UV 1101, Biotech Photometer), and their amplification was conducted with Real-Time PCR. The results of the assessments revealed that the highest nucleic acid concentration were obtained with the conventional methods, while they exhibited significant drawbacks such as long duration of the testing time, difficulty in application, and higher contamination risk.
\end{abstract}

Key Words: HBV, HCV, PCR, spectrophotometer, amplification.

\section{Introduction}

Hepatitis B virus (HBV) is an important health problem in our country as it is in the whole world because it leads to acute hepatitis as well as chronic hepatitis, liver cirrhosis and hepatocellular carcinoma (HCC). Hepatitis B Virus Surface Antigen (HBsAg) positivity rate is 0.1 $0.2 \%$ in the United States (USA) and Northern Europe, while it is around $10-15 \%$ in Africa and Far East. In our country, the rates obtained in various studies vary between 5-14\% [1]. Over the world, more than 2 billion people live with HBV at some time in their lives [2]. Of these, 350 million become chronic carriers of the virus $[3,4]$.

Another important health problem is the hepatitis $\mathrm{C}$ virus. The fact that HCV has a much higher chronicity $(80 \%)$ than $\mathrm{HBV}$, leading to liver cirrhosis and hepatocellular carcinoma, further increases the importance of this virus. In spite of all these developments, it is important to know that there are also intensive problems with HCV. Natural course, genotypic differences in the virus, uncertainties in treatment and difficulties in vaccination studies are the main problems There are 170 million chronic liver patients infected with hepatitis $\mathrm{C}$ virus in the world [5].
Serological tests that detect HBV and HCV antigens or antibodies in the patient's serum are commonly used to determine the stage of infection and to assess infectivity. Molecular biology techniques have been used to detect various mutations in cases where serologic tests are inadequate and diagnosis is not made in atypical serological cases, antiviral therapy is monitored. Quantitative PCR methods are also used to measure HBV DNA and HCV RNA levels due to their high sensitivity. The Real Time PCR technique, which has become increasingly popular in recent times, is a rapid and simple test that allows the quantitation of HBV DNA and HCV RNA [1]. There are many literature related to the subject $[6,7,8,9,10]$.

In this study, it was aimed to investigate isolation methods of nucleic acids by using spectrophotometer and Real Time PCR technique in Hepatitis B and Hepatitis C viruses, which have become a major health problem in the world and in our country.

\section{Materials And Methods}

In our study, Fluorion HBV QNP 2.0 was used as the HBV DNA standard and Fluorion HCV QNP 2.1 as the 
HCV RNA standard. Concentrations of standards ranged from 102 to $106 \mathrm{IU} / \mathrm{mL}$. Roboscreen and NucleoSpin kits were used for HBV DNA and HCV RNA. In the conventional method, HBV DNA is purified by PhenolChloroform Isolation Method; HCV-RNA was purified by Guanidine Thiosionate Isolation Method. The isolated viral nucleic acids were stored at -20 (deg.) C. until the day of operation. On the day when the work was to be done, samples were brought to room temperature and absorbance values were measured against a blind tube at $260 \mathrm{~nm}$ and $280 \mathrm{~nm}$ wavelengths in a spectrophotometer (WPA UV 1101 Biotech Photometer). Then DNA and RNA samples were amplified by Real Time PCR method $[6,7,8,9,10]$.

\section{Results and Discussion}

Measurement of total quantities of DNA isolated from Hepatitis B virus using two different brand kits and conventional methods was performed in spectrophotometer and A260, A280, A260 / 280 ratios were measured.

The total amount of DNA $(\mu \mathrm{g} / \mathrm{ml})$ was calculated as 50 $x$ O.D x D.F. and the results are shown in Table 1,2,3. The amount of total RNA $(\mu \mathrm{g} / \mathrm{ml})$ was calculated as 40 $\times$ O.D $\times$ D.F. and the results are shown in Table 4,5,6 The results of isolation times of nucleic acids are shown in Tables 7 and 8.

When we look at spectrophotometric results of our study, we see that we obtained the most efficient values by conventional methods (phenol-chloroform and guanidine thiosynthesis method). Although these two methods give higher values for HBV DNA and HCV RNA compared to the isolation with the other two commercial kits, they lead to a lot of time loss. HBV DNA isolation step $60 \mathrm{~min}$ with Roboscreen kit; 70 min with NucleoSpin brand kit; phenol-chloroform method for $2880 \mathrm{~min}$. The time loss in the phenol-chloroform method was found to be much higher than the other two kit methods.

In the case of HCV RNA, the isolation step was performed with the Roboscreen kit for $60 \mathrm{~min} ; 70 \mathrm{~min}$ with NucleoSpin brand kit; guanidine-thiocyanate method $300 \mathrm{~min}$. has been determined. According to the other two kit methods, Guanidine-thiocyanate method was found to last longer. In view of the fact that the PCR technique is a fast and simple test, time loss of the isolation phase is very important if it is considered preferred for diagnosis and treatment of the patient.

When we look at risk analysis for nucleic acid isolation according to our findings, the buffer solutions and solutions required for isolation by conventional methods are prepared manually by the investigator. In the NucleoSpin and Roboscreen kit method, all necessary buffer solutions are available in commercial kits. The preparation of the chemicals takes a long time and is a very troublesome business. During the preparation of chemicals, more than one staff member is needed. In addition, some chemicals have high toxicity. This is a great disadvantage for employees. In the conventional method, the use of consumables and devices is also very common during the preparation of chemicals. The greater the use of consumables and devices, the greater the risk of contamination. It was also found that the contamination risk increased during the preparation of the buffer solutions. In the NucleoSpin and Roboscreen kit method, all necessary buffer solutions are available in commercial kits. Therefore, only the lyophilized ones should be solved. This does not lead to time loss. In both kit methods, the toxic effects of the solutions are negligible. The researcher is able to prepare for work without needing other staff. While the risk of contamination is highest in conventional methods; The Roboscreen brand kit is at least the NucleoSpin brand kit, and the membrane is being used with the colon columns.

In the study of Fawcett [11], when we looked at the literature, the results of our work on spectrophotometric measurement as a result of conventional isolation of plasmid DNA yielded similar results. Although Kephart [16] does not give the same values as our study because he works full-blooded as a result of isolation from human blood using the SV Total RNA isolation system, the A260 / 280 values support our findings. Chomczynski et al. [12] performed RNA isolation from mouse tissue by the method of acid guanidium thiocyanate-phenolchloroform (AGPC) and guanidium-CsCl methods. Although the total RNA and DNA amounts differ from our study, the A260/280 ratio supports our findings. Akin et al. [13] used two different isolation methods for RNA from infectious Bursal disease virus; The obtained RNAs, AGPC and proteinase $\mathrm{K}$, were measured spectrophotometrically and the A260 / 280 ratio was reported as 1.83 . The results support our work, but there is no individual comparison because the virus being studied is different.

Table 1. Measured values of viral DNA isolated with Roboscreen kit by spectrophotometer

\begin{tabular}{|c|c|c|c|c|c|}
\hline Standard & Kit & $\mathbf{A 2 6 0}$ & $\mathbf{A 2 8 0}$ & $\mathbf{A 2 6 0} / \mathbf{2 8 0}$ & Total DNA ( $\boldsymbol{\mu g} / \mathbf{m l})$ \\
\hline Standard 1 & Roboscreen & 0,075 & 0,069 & 1,086 & 75 \\
\hline Standard 2 & Roboscreen & 0,085 & 0,079 & 1,075 & 85 \\
\hline Standard 3 & Roboscreen & 0,096 & 0,083 & 1,156 & 96 \\
\hline Standard 4 & Roboscreen & 0,093 & 0,081 & 1,148 & 93 \\
\hline Standard 5 & Roboscreen & 0,098 & 0,087 & 1,126 & 98 \\
\hline
\end{tabular}


Celal Bayar University Journal of Science

Volume 14, Issue 3, 2018, p 351-355

Table 2. Measurement values of viral DNA isolated with NucleoSpin kit by spectrophotometer

\begin{tabular}{|c|c|c|c|c|c|}
\hline Standard & Kit & $\mathbf{A} 260$ & $\mathbf{A} 280$ & $\mathbf{A} 260 / 280$ & Total DNA ( $\mathbf{\mu g} / \mathbf{m l})$ \\
\hline Standard 1 & NucleoSpin & 0,030 & 0,027 & 1,111 & 75 \\
\hline Standard 2 & NucleoSpin & 0,023 & 0,019 & 1,210 & 57,5 \\
\hline Standard 3 & NucleoSpin & 0,032 & 0,029 & 1,103 & 80 \\
\hline Standard 4 & NucleoSpin & 0,037 & 0,035 & 1,057 & 92,5 \\
\hline Standard 5 & NucleoSpin & 0,039 & 0,036 & 1,083 & 97,5 \\
\hline
\end{tabular}

Table 3. The measured values of viral DNA isolated by phenol-chloroform isolation method by spectrophotometer

\begin{tabular}{|c|c|c|c|c|c|}
\hline Standard & Conventional Method & $\mathbf{A}_{260}$ & $\mathbf{A}_{280}$ & A260/280 & Total DNA $(\mu \mathrm{g} / \mathrm{ml})$ \\
\hline Standard 1 & Phenol-chloroform & 0,043 & 0,041 & 1,048 & 107,5 \\
\hline Standard 2 & Phenol-chloroform & 0,036 & 0,027 & 1,333 & 90 \\
\hline Standard 3 & Phenol-chloroform & 0,038 & 0,036 & 1,055 & 95 \\
\hline Standard 4 & Phenol-chloroform & 0,041 & 0,037 & 1,108 & 102,5 \\
\hline Standard 5 & Phenol-chloroform & 0,042 & 0,039 & 1,076 & 105 \\
\hline
\end{tabular}

Table 4. Measured values of viral RNAs isolated with Roboscreen kit by spectrophotometer

\begin{tabular}{|c|c|c|c|c|c|}
\hline Standard & Kit & $\mathbf{A 2 6 0}$ & $\mathbf{A 2 8 0}$ & $\mathbf{A 2 6 0} / \mathbf{2 8 0}$ & Total RNA ( $\mathbf{M g} / \mathbf{m l})$ \\
\hline Standard 1 & Roboscreen & 0,102 & 0,103 & 0,990 & 81,6 \\
\hline Standard 2 & Roboscreen & 0,106 & 0,096 & 1,104 & 84,8 \\
\hline Standard 3 & Roboscreen & 0,114 & 0,108 & 1,055 & 91,2 \\
\hline Standard 4 & Roboscreen & 0,118 & 0,111 & 1,063 & 94,4 \\
\hline Standard 5 & Roboscreen & 0,134 & 0,129 & 1,038 & 107.2 \\
\hline
\end{tabular}

Table 5. Measured values of viral RNAs isolated by NucleoSpin kit by spectrophotometer

\begin{tabular}{|c|c|c|c|c|c|}
\hline Standard & Kit & $\mathbf{A}_{\mathbf{2 6 0}}$ & $\mathbf{A}_{\mathbf{2 8 0}}$ & $\mathbf{\mathbf { A } _ { 2 6 0 } / \mathbf { 2 8 0 }}$ & Total RNA ( $\boldsymbol{\mu g} / \mathbf{m l})$ \\
\hline Standard 1 & NucleoSpin & 0,037 & 0,034 & 1,088 & 74 \\
\hline Standard 2 & NucleoSpin & 0,042 & 0,039 & 1,076 & 84 \\
\hline Standard 3 & NucleoSpin & 0,043 & 0,045 & 0,955 & 86 \\
\hline Standard 4 & NucleoSpin & 0,034 & 0,031 & 1,096 & 68 \\
\hline Standard 5 & NucleoSpin & 0,053 & 0,046 & 1,152 & 106 \\
\hline
\end{tabular}

Table 6. Measured values of RNAs isolated by guanidine thiocyanate isolation method by spectrophotometer

\begin{tabular}{|c|l|c|c|c|c|}
\hline Standard & Conventional Method & $\mathbf{A}_{\mathbf{2 6 0}}$ & $\mathbf{A} \mathbf{2 8 0}$ & $\mathbf{A} \mathbf{2 6 0} / \mathbf{2 8 0}$ & Total RNA ( $\boldsymbol{\mu g} / \mathbf{m l})$ \\
\hline Standard 1 & Guanidine-thiocyanate & 0,043 & 0,039 & 1,102 & 86 \\
\hline Standard 2 & Guanidine-thiocyanate & 0,046 & 0,045 & 1,022 & 92 \\
\hline Standard 3 & Guanidine-thiocyanate & 0,050 & 0,051 & 0,980 & 100 \\
\hline Standard 4 & Guanidine-thiocyanate & 0,049 & 0,043 & 1,139 & 98 \\
\hline Standard 5 & Guanidine-thiocyanate & 0,054 & 0,049 & 1,102 & 108 \\
\hline
\end{tabular}


Celal Bayar University Journal of Science

Volume 14, Issue 3, 2018, p 351-355

3.1. Findings in Risk Analysis:

Table 9. HBV DNA isolation phase risk analysis

\begin{tabular}{|c|c|c|c|c|c|c|}
\hline Kit & $\begin{array}{c}\text { Contamination } \\
\text { Risk }\end{array}$ & $\begin{array}{c}\text { Required } \\
\text { Personnel }\end{array}$ & $\begin{array}{c}\text { Chemical } \\
\text { Toxicity }\end{array}$ & Preliminary & Supplies & $\begin{array}{c}\text { Required } \\
\text { Device }\end{array}$ \\
\hline Roboscreen & + & + & + & + & + & + \\
\hline NucleoSpin & ++ & + & + & + & + & + \\
\hline $\begin{array}{c}\text { Phenol-chloroform } \\
\text { method }\end{array}$ & +++ & +++ & +++ & +++ & +++ & +++ \\
\hline
\end{tabular}

(+: low, ++: medium, +++: high)

Table 10. HCV RNA Isolation phase risk analysis

\begin{tabular}{|c|c|c|c|c|c|c|}
\hline Kit & $\begin{array}{c}\text { Contamination } \\
\text { Risk }\end{array}$ & $\begin{array}{l}\text { Required } \\
\text { Personnel } \\
\end{array}$ & $\begin{array}{c}\text { Chemical } \\
\text { Toxicity }\end{array}$ & Preliminary & Supplies & $\begin{array}{c}\text { Required } \\
\text { Device }\end{array}$ \\
\hline Roboscreen & + & + & + & + & + & + \\
\hline NucleoSpin & ++ & + & + & + & + & + \\
\hline $\begin{array}{l}\text { Guanidine } \\
\text { thiocyanate method }\end{array}$ & +++ & +++ & +++ & +++ & +++ & +++ \\
\hline
\end{tabular}

(+: low, ++: medium, +++: high)

\section{Conclusion}

As a result, the use of a kit is more advantageous despite its high cost. It is important to get fast results in the diagnosis of $\mathrm{HBV}$ and $\mathrm{HCV}$. HBV, HCV load, serological tests of the patient, whether the patient has received treatment, liver enzymes and the clinical condition of the patient should be evaluated as a whole when evaluating $\mathrm{HBV}$ and $\mathrm{HCV}$ infections as well as PCR results. Despite the high sensitivity of quantitative PCR methods, some problems have been reported, such as standardization, contamination, and reproducibility. Therefore, careful attention to this issue, especially when evaluating patients with low HBV DNA positivity, suggests that serologically incompatible it is reported that it is useful to question the cases and repeat the PCR test if necessary [14-20].

\section{Acknowledgements}

This study is a part of the Master Thesis of Nagehan ŞAKURCU (GÜNDÜZ) and financially supported by Manisa Celal Bayar University Scientific Research Project Coordination Unit (Project number: BAP-2006010).

\section{References}

1. Saveci E. Prevalence Hepatitis B seroprevalence. Ministry of Health Taksim Training and Research Hospital Gynecology and Obstetrics Clinic. Family Medicine Specialization Thesis, 2006, İstanbul.

2. Hochberger, S., Althof, D., Gallegos de Schrott, R., Nachbaur, N. Röck, H., Leying, H. Fully automated quantitation of Hepatitis B virus (HBV) DNA in human plasma by the COBAS ${ }^{\circledR}$
AmpliPrep/COBAS ${ }^{\circledR}$ TaqMan ${ }^{\circledR}$ System. Journal of Clinical Virology, 2006, 35: 373-380.

3. Şanlıdağ, T., Akçalı, S., Özbakkaloğlu, B.Serum hepatitis B DNA: stability in relation to multiple freeze-thaw procedures.Journal of Virological Methods, 2005, 123: 49-52.

4. Kidd-Ljunggren, K., Holmberg, A., Blackberg, J., Lindqvist, B.High levels of hepatitis B virüs DNA in body fluids from chronic carriers. Journal of Hospital Infection, 2006, 64: 352-357.

5. Beguiristain N, Robertson DH, Gómez J. RNase III cleavage demonstrates a long range RNA: RNA duplex element flanking the hepatitis $\mathrm{C}$ virus internal ribosome entry site. Nucleic Acids Research, 2005, 33(16): 5250-5261.

6. Berger A, Preiser W, Doerr WH. The role of viral load determination for the management of human immunodeficiency virüs, hepatitis $B$ virus and hepatitis $C$ virus infection. Journal of Clinical Virology, 2001, 20:23-30.

7. Chien HJ, Lee SD, Cheng TY, Yeh HS, Chou PW, Chen HP. A novel fluorescence quantification method for polymerase chain reaction system. Optics Communications, 2006, 266: 744-750.

8. Leb V, Stöcher Valentine-Thon E, Hölzl G, Kessler H, Stekel H, Berg J. Fully Automated, Internally Controlled Quantification of Hepatitis B Virus DNA by Real-Time PCR by Use of the MagNA Pure LC and LightCycler Instruments. Journal of Clinical Microbiology, 2003, 42(2): 585-590.

9. Simpson RP, Yu HX, Redza MZ, Anson GJ, Chan HS, Lin Y. Quantification of hepatitis B virus DNA using competitive PCR and a scintillation proximity assay. Journal of Virological Methods, 1997, 69: 197-208.

10. Sun R, Schilling $W$, Jayakar $H$ et al. Simultaneous extraction of hepatitis $\mathrm{C}$ virus (HCV), hepatitis B virus, and HIV-1 from plasma and detection of HCV RNA by a reverse transcriptase-polymerase 
Celal Bayar University Journal of Science

chain reaction assay designed for screening pooled units of donated blood. Transfusion Complications, 1999, 39: 1111-1119.

11. Fawcett WT. Isolation of high-quality large plasmid DNA Focus, 1999, 21(1)

12. Chomczynski P, Sacchi N. Single-step method of RNA isolation by acid guanidinium thiocyanate-phenol-chloroform extraction. Analytical Biochemistry, 1987, 162: 156-159.

13. Akin A, Wu CC, Lin LT. A comparison of two RNA isolation methods for double-stranded RNA of infectious bursal disease virus. Journal of Virological Methods, 1998, 74:179-184.

14. Kerur N, Jhala MK, Joshi CG. Genetic characterization of Indian pestedes petits ruminants virus (PPRV) by sequencing and phylogenetic analysis of fusion protein and nucleoprotein gene segments. Res Vet Sci, 2008, 85: 176-183,

15. Munir M, Zohari S, Saeed A, Khan QM, Abubakar M, LeBlanc N, Kanu S, Sankoh FA, Berg M, Barrie ML, Ståhl K. Genetic characterization of peste des petits ruminants virus, Sierra Leone. Emerg Infect Dis, 2012, 18:193-195
16. Luka PD, Erume J, Mwiine FN, Ayebazibwe C, Shamaki D. Molecular characterization and phylogenetic study of peste des petits ruminants viruses from North central states of Nigeria. BMC Vet Res, 2011, $7: 32$

17. Kwiatek O, Ali YH, Saeed IK, Khalafalla AI, Mohamed OI, Obeida AA, Abdelrahman MB, Osman HM, Taha KM, Abbas Z, Harrak M, Lhor Y, Diallo A, Lancelot R, Albina E, Libeau G. Asian Lineage of Peste des Petits Ruminants Virus, Africa. Emerg Infect Dis, 2011, 17: 1223-1231

18. Munir M, Zohari S, Saeed A, Khan QM, Abubakar M, LeBlanc N, Berg M. Detection and phylogenetic analysis of peste des petits ruminants virus isolated from outbreaks in Punjab, Pakistan. Transbound Emerg Dis, 2012, 59: 85-93

19. De Nardi M, Lamin Saleh SM, Batten C, Oura C, Di Nardo A, Rossi D. First evidence of peste des petits ruminants (PPR) virus circulation in Algeria (Sahrawi Territories): Outbreak investigation and virüs lineage identification. Transbound Emerg Dis, 2012, 59: 214-222

20. 20. Sevik M. Molecular Detection of Peste des petits ruminants virüs from different organs/tissues of naturally infected animals. Kafkas Univ Vet Fak Derg, 2014, 20: 165-168 